\title{
ANTIBACTERIAL ACTIVITY OF ESSENTIAL OILS AGAINST PATHOGENS OF IMPORTANCE IN CAPRINE AND OVINE MASTITIS ${ }^{1}$
}

\author{
RODOLFO FURLANI ${ }^{2}$, MAURA MARINETE DE SOUSA ${ }^{2}$, GIOVANNA NOGUEIRA DA SILVA AVELINO \\ OLIVEIRA ROCHA ${ }^{2}$, FLÁVIA CARTAXO RAMALHO VILAR ${ }^{2}$, RICARDO CARTAXO RAMALHO ${ }^{3}$, \\ RODOLFO DE MORAES PEIXOTO ${ }^{2 *}$
}

\begin{abstract}
Mastitis is an important infirmity that affects dairy goats and sheep flocks. Antimicrobials are widely used in mastitis therapy; however, the phenomenon of bacterial resistance has sparked interest in therapeutic alternatives, especially the research on essential oils from several plant species. Therefore, this study aimed to evaluate the antimicrobial activity of essential oils against pathogens of importance in caprine and ovine mastitis. The essential oils were obtained by hydrodistillation and the chemical composition was analyzed by gas chromatography coupled to mass spectrometry (GC-MS). The minimum inhibitory concentration (MIC) and minimum bactericidal concentration (MBC) tests were performed to evaluate the antimicrobial activity of the essential oils (EO) of four plants. Fifteen bacterial isolates, previously identified as Staphylococcus spp. and Staphylococcus aureus, were used. The following plant species were used against the 15 bacterial isolates: Lippia origanoides "alecrim pimenta," Lippia alba "erva cidreira," Cymbopogon citratus "capim-santo," and Ocimum basilicum "manjericão." The first three essential oils presented antimicrobial activity against $100 \%$ of the isolates $(15 / 15)$, with MICs of $560 \mu \mathrm{g} \mathrm{mL} \mathrm{mL}^{-1}, 1,173 \mu \mathrm{g} \mathrm{mL}$, and $1,280 \mu \mathrm{g} \mathrm{mL} \mathrm{m}^{-1}$, and MBCs of $613 \mu \mathrm{g} \mathrm{mL}^{-1}, 1,226 \mu \mathrm{g} \mathrm{mL}^{-1}$, and 1,333 $\mu \mathrm{g} \mathrm{mL}^{-1}$, respectively. Nevertheless, the essential oil of $O$. basilicum, which was also tested, exerted no activity against any of the isolates. Carvacrol, citral, geraniol, and estragole were some of the major compounds found. These results can aid other studies that aim to use these essential oils as potential products for subsequent use in the treatment of mastitis in small ruminants.
\end{abstract}

Keywords: Small ruminants. Antimicrobial potential. Natural products. Staphylococcus spp.

\section{ATIVIDADE ANTIBACTERIANA DE ÓLEOS ESSENCIAIS FRENTE AOS PATÓGENOS DE IMPORTÂNCIA NA MASTITE CAPRINA E OVINA}

\begin{abstract}
RESUMO - A mastite é uma importante enfermidade que acomete rebanhos leiteiros de cabras e ovelhas. Os antimicrobianos são amplamente utilizados na terapia da mastite, contudo, o fenômeno da resistência bacteriana tem despertado o interesse por alternativas terapêuticas, destacando-se a pesquisa com óleos essenciais de diversas plantas. Dessa forma, o objetivo deste trabalho foi avaliar a atividade antibacteriana de óleos essenciais frente a patógenos de importância na mastite caprina e ovina. A obtenção dos óleos essenciais foi realizada utilizando a técnica de hidrodestilação e a composição química foi analisada através de cromatografia gasosa acoplada à espectrometria de massas (CG-EM). Para avaliar a atividade antibacteriana dos óleos essenciais (OE) de quatro plantas, utilizou-se os testes de Concentração Inibitória Mínima (CIM) e Concentração Bactericida Mínima (CBM). Foram utilizados 15 isolados bacterianos previamente identificados como Staphylococcus spp. e Staphylococcus aureus. Utilizaram-se as seguintes espécies de plantas: Lippia origanoides (alecrim-pimenta), Lippia alba (erva cidreira), Cymbopogon citratus (capim-santo) e Ocimum basilicum (manjericão) frente aos 15 isolados bacterianos. Os três primeiros óleos essenciais apresentaram atividade antibacteriana sobre $100 \%$ dos isolados (15/15), com as CIMs de 560, 1173 e $1280 \mu \mathrm{g} \mathrm{mL}^{-1}$, e CBMs de 613,1226 e $1333 \mu \mathrm{g} \mathrm{mL}{ }^{-1}$, respectivamente. Por outro lado, o óleo de Ocimum basilicum (manjericão), não exerceu atividade sobre nenhum isolado (0/15). O carvacrol, citral, geronial e o estragol foram alguns dos compostos majoritários encontrados. Estes resultados podem auxiliar outras pesquisas que visam à utilização destes óleos essenciais como produtos potenciais e que possam futuramente auxiliar no tratamento da mastite em pequenos ruminantes.
\end{abstract}

Palavras-chave: Pequenos ruminantes. Potencial antimicrobiano. Produtos naturais. Staphylococcus spp.

\footnotetext{
${ }^{*}$ Corresponding author

${ }^{1}$ Received for publication in $06 / 24 / 2020$; accepted in 04/20/2021.

Paper of the Experimentation Research Group.

${ }^{2}$ Instituto Federal de Educação, Ciência e Tecnologia do Sertão Pernambucano, Petrolina, PE, Brazil; rodolfogottardo@hotmail.com ORCID: 0000-0002-9698-9380, maura.marisousa@gmail.com - ORCID: 0000-0002-5109-5156, giovanna.nogueira@ifsertao-pe.edu.br ORCID: 0000-0003-2818-2216, flavia.cartaxo@ifsertao-pe.edu.br - ORCID: 0000-0002-4725-0889, rodolfo.peixoto@ifsertao-pe.edu.br, ORCID: 0000-0002-5757-5935.

${ }^{3}$ Pharmaceutical Sciences Department, Universidade Federal da Paraíba, João Pessoa, PB, Brazil; crtx@uol.com.br - ORCID: 0000- 00015207-2813.
} 


\section{INTRODUCTION}

Mastitis is an infirmity that affects dairy goats and sheep flocks. It is characterized by inflammation of the mammary gland, with the intensity of the disease being determined by the nature and virulence factors of the bacteria or the group of bacteria, by the resistance of the agent to antibiotics, and by other factors related to the host (GELASAKIS et al., 2015; GABLI et al., 2019). The most common pathogens associated with intramammary infections in small ruminants, with the ability to cause clinical and subclinical mastitis, are those of the genus Staphylococcus (OLECHNOWICZ; JAŚKOWSKI, 2014).

Bacterial mastitis has a great impact on milk production, resulting in large financial losses (ZHAO et al., 2015). Positive milk samples for $S$. aureus indicate health risks for both the animal and the consumer (MERZ; STEPHAN; JOHLER, 2016). The risk of foodborne infection is low in countries where pasteurization is applied to most dairy products. However, this risk exists with the consumption of raw milk, especially because several products made from the non-pasteurized milk of goats and sheep are consumed raw (RAINARD et al., 2017; GELASAKIS, 2016; MERZ; STEPHAN; JOHLER, 2016).

Staphylococcal mastitis is a complex disease and its main agent, Staphylococcus aureus, is a pathogen with the potential to express several virulence factors. This results in low efficacy of both the currently available vaccines and the antimicrobial treatments (RAINARD et al., 2017), with the latter consisting of the conventionally applied treatment, which contributes to microbial resistance when used in an unguided way (GANDA et al., 2016).

Consequently, there is a need to search for new alternatives aimed at postponing the emergence of resistance to antimicrobials, considering the fact that this is one of the main issues in the treatment of mastitis (CADES et al., 2017), in addition to the presence of antimicrobial residues in dairy foods and the ambient environment (ALMEIDA et al., 2016). According to Oliveira et al. (2019), the use of products, such as extracts, made from plants that grow in abundance in Brazilian soils for the control of $S$. aureus is one of the most explored lines of research in biotechnology.

Studies on the antimicrobial activity of the essential oils of several plants have demonstrated a positive potential against several bacteria as they are products of vegetal origin that present a variety of bioactive molecules in its composition. For this reason, they have emerged as an option in the production of herbal medicines for the control of mastitis, considering their potential for use as alternative products, with a lower toxic potential associated with applications in both animal and human health (NASCIMENTO; SÁ; FORTUNA,
2020; REIS et al., 2020; ALMEIDA et al., 2016; ALMEIDA et al., 2010). Given this problem, this study aimed to evaluate the antimicrobial activity of essential oils against important pathogens of caprine and ovine mastitis.

\section{MATERIAL AND METHODS}

Minimum inhibitory concentration (MIC) and minimum bactericidal concentration (MBC) tests were used to evaluate the antimicrobial activity of the essential oils (EO) of four plants. To perform the tests, we used 14 bacterial isolates, previously identified as Staphylococcus spp. and Staphylococcus aureus, originating from milk cultures prepared from goat and sheep milk samples. These microorganisms belonged to the bacterial collection of the Laboratory of Food Quality Control of Federal Institute SERTÃO - PE, Campus Petrolina Zona Rural, where the research was conducted. We also used a strain of methicillin-sensitive Staphylococcus aureus (MSSA), an American Type Culture Collection (ATCC) reference strain (lineage ATCC 25923), creating a total of 15 isolates in this study.

The essential oils used were extracted from the respective plants grown in the Organic Medicinal Orchard of IF SERTÃO - PE. These included: Lippia origanoides "alecrim pimenta," Lippia alba "erva cidreira," Cymbopogon citratus "capim-santo," and Ocimum basilicum "manjericão." The plant material was deposited and registered at the Prisco Viana Herbarium of the Federal University of Ceará (UFC), and can be identified with the following registration numbers: L. origanoides-EAC41823; $L$. alba-EAC46711; C. citratus-EAC46090; and $O$. basilicum-EAC46711.

\section{Extraction of the essential oil}

Extraction of the essential oil from each species was performed by hydrodistillation using a Clevenger-type apparatus for two hours. The hydrodistillation process used $100 \mathrm{~g}$ samples of fresh leaves and flowers that were collected at 10:00 a.m. Triplicate samples were identified and stored in a refrigerator. The extractions were performed at the Chemistry Laboratory of IF SERTÃO - PE.

\section{Identification and quantification of major compounds}

The characterization of the major components of the essential oil of each species was performed using a gas chromatograph coupled to a mass spectrometer (Shimadzu®, GCMS-QP2010 Ultra). Before injecting the essential oil from each plant, a $20 \mathrm{~mL}$ aliquot of the oil was transferred to a $10 \mathrm{~mL}$ volumetric flask containing HPLC-grade n-hexane. 
The ionization of the components was performed by electron impact with ionization energy at $0.84 \mathrm{kV}$. The spectrometer was operated in SCAN mode, covering a mass range of $40 \mathrm{~m} / \mathrm{z}$ to $600 \mathrm{~m} / \mathrm{z}$. The ion source temperature was $280{ }^{\circ} \mathrm{C}$ and the injector temperature was programmed to $150{ }^{\circ} \mathrm{C}$. A capillary column (RTX-5MS) was used as the stationary phase, composed of $5 \%$ diphenyl and $95 \%$ dimethylpolysiloxane, with a $30 \mathrm{~m}$ length, a 0.25 $\mathrm{mm}$ internal diameter, and a $0.25 \mu \mathrm{m}$ particle size. The column was heated from an initial temperature of $50{ }^{\circ} \mathrm{C}$, with a heating rate of $5{ }^{\circ} \mathrm{C} / \mathrm{min}$, until the final temperature was $280{ }^{\circ} \mathrm{C}$. Helium was used as the carrier gas at a flow rate of $3 \mathrm{~mL} / \mathrm{min}$ and a split ratio of $1: 10$. The solvent cut time of 2.5 min was used to eliminate the peak of the sample diluent (nhexane).

The constituents were identified by comparing the spectra and the mass fragments obtained in the chromatographic analysis against the databases of the spectral libraries Wiley9, NIST08, and FFNSC1.3, available in the software of the equipment.

\section{Evaluation of the antimicrobial activity}

The essential oils underwent a dilution process, resulting in two solutions. First, $1 \mathrm{~g}$ of each EO was diluted with methanol to a concentration of $640 \mathrm{mg} \mathrm{mL}^{-1}$ (solution I). Afterward, this solution was diluted to a 1:100 ratio in Muller-Hinton broth (MH) to obtain a concentration of $6400 \mu \mathrm{g} \mathrm{mL}-1$, constituting solution II.

The determination of the minimum inhibitory concentration (MIC) and the minimum bactericidal concentration (MBC) were done according to the guidelines of the document M7-A7 (Clinical and Laboratory Standard Institute (CLSI, 2006). The determination of the MIC involved the distribution of $200 \mu \mathrm{L}$ of $\mathrm{MH}$ broth into the wells of a microdilution plate. Thereafter, $200 \mu \mathrm{L}$ of the solution was added to the first well and after homogenization it was transferred to the second well, and so on, to obtain the final concentrations of $3,200 \mu \mathrm{g} \mathrm{mL}{ }^{-1}, 1,600 \mu \mathrm{g} \mathrm{mL} \mathrm{m}^{-1}, 800 \mu \mathrm{g} \mathrm{mL} \mathrm{m}^{-1}$, $400 \mu \mathrm{g} \mathrm{mL}^{-1}, 200 \mu \mathrm{g} \mathrm{mL}^{-1}, 100 \mu \mathrm{g} \mathrm{mL}^{-1}, 50 \mu \mathrm{g} \mathrm{mL}^{-1}$, and $25 \mu \mathrm{g} \mathrm{mL}^{-1}$.

The inoculation consisted of a suspension in a saline solution $(0.85 \%)$ with turbidity equivalent to that of a 0.5 -tube of the MacFarland standards $(1 \times$

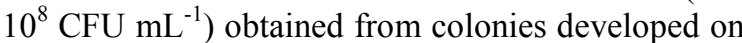
$\mathrm{MH}$ agar. Afterward, the dilution of this suspension was performed at a 1:100 ratio in $\mathrm{MH}$ broth, thus obtaining an inoculum equivalent to $1 \times 10^{4} \mathrm{CFU}$ $\mathrm{mL}^{-1}$. From this suspension, $10 \mu \mathrm{L}\left(1 \times 10^{4} \mathrm{CFU}\right)$ was inoculated into each well that had already contained the EO to be tested. After the preparation of the microplates, incubation was performed at $35^{\circ}$ $\mathrm{C}$ for $24 \mathrm{~h}$ in aerobiosis. The MICs were determined through a visual examination of the turbidity of the wells by observing the lowest EO concentration that was able to inhibit growth. An MIC of $50 \%$ was defined as the lowest concentration able to inhibit $50 \%$ of the isolates.

The determination of the minimum bactericidal concentration (MBC) began in the wells in which there was no visible bacterial growth. From these, an aliquot of $10 \mu \mathrm{L}$ was removed and sown on the surface of a Petri dish containing $\mathrm{MH}$ agar. After $48 \mathrm{~h}$ of incubation at $35{ }^{\circ} \mathrm{C}$, the $\mathrm{MBCs}$ were determined as the lowest $\mathrm{EO}$ concentration able to cause the death of the inoculum. All assays were performed in triplicate.

\section{RESULTS AND DISCUSSION}

The chemical constituents of the $L$. origanoides, L. alba, C. citratus, and O. basilicum oils used in this study were identified and quantified, and their respective results are expressed in Table 1.

Table 1. Major compounds presented in the plant species analyzed.

\begin{tabular}{ll}
\hline \multicolumn{1}{c}{ Species } & Major compounds (\%) \\
\hline Lippia origanoides & carvacrol (44.5\%), p-cymene (14.06\%), and terpinene (12.43\%) \\
Lippia alba & citral (43.74\%) and neral (31.97\%) \\
Cymbopogon citratus & geraniol (41.65\%), neral (31.89\%), and myrcene $(12.65 \%)$ \\
Ocimum basilicum & estragole $(54.80 \%)$, eucalyptol $(13.54 \%)$, and linalool $(8.25 \%)$ \\
\hline
\end{tabular}


Chromatography revealed that the essential oils of the analyzed species presented a diverse group of major compounds, some of which have been widely cited in the literature. According to Araújo et al. (2015), the antibacterial action of essential oils is directly related to their chemical composition. Additionally, Millezi et al. (2014) reinforced that, in Brazil, studies have described the existence of different chemical characteristics between the essential oils of the same species that are grown in different geographic regions of the globe. They also noted that the chemical composition can vary as a function of several factors, including the environmental and genetic characteristics of the species.

In a study performed by Freitas et al. (2013), the phenolic monoterpene, carvacrol demonstrated promising results in the modulation of antimicrobial activity against $S$. aureus. Furthermore, Pozzo et al. (2011) demonstrated that the major fraction of carvacrol demonstrated significant antimicrobial activity. According to Burt (2004), in the essential oils that presented higher activity against food pathogens, such as $S$. aureus, carvacrol was identified as an efficient antibacterial substance. Synergism was also observed between carvacrol and its precursor, $p$-cymene.

In the evaluation of the essential oils of Cymbopogon citratus and Ocimum basilicum performed by Valeriano et al. (2012), the chemical composition comprised $38.43 \%$ geranial, $31.12 \%$ neral, $4.21 \%$ linalool, and $2.53 \%$ myrcene in Cymbopogon citratus, while Ocimum basilicum consisted of $59.19 \%$ linalool. Furthermore, these essential oils presented antimicrobial activity. The major constituents found in these essential oils resemble those found in the present study. The chemical composition of the essential oils includes a variety of substances and their mechanism of action would most likely involve several targets in the bacterial cell. The damage caused to the cell membrane that modifies its permeability is an example of the antibacterial action of some compounds (BURT, 2004).

Table 2 presents the results of the antibacterial activity of the essential oils of L. origanoides, L. alba, and C. citratus against 15 bacterial isolates. These essential oils presented antibacterial activity against $100 \%$ of the isolates $(15 / 15)$. Nevertheless, the $O$. basilicum essential oil exerted no antibacterial activity on any of the isolates $(0 / 15)$.

According to the results expressed in Table 2, the essential oil that presented the best antimicrobial activity, which stood out among the others, was the L. origanoides $\mathrm{EO}$, with $\mathrm{MIC}$ and $\mathrm{MBC}$ means of $560 \mu \mathrm{g} \mathrm{mL}^{-1}$ and $613 \mu \mathrm{g} \mathrm{mL}^{-1}$, respectively. The $50 \%$ MIC of this EO was $400 \mu \mathrm{g} \mathrm{mL}^{-1}$ in $9 / 15$, which was the lowest among all the evaluated.

Table 2. Antimicrobial activity of the essential oils of the species L. origanoides, L. alba, and C. citratus against mastitis-causing agents, 2018.

Antimicrobial activity

EO of the species

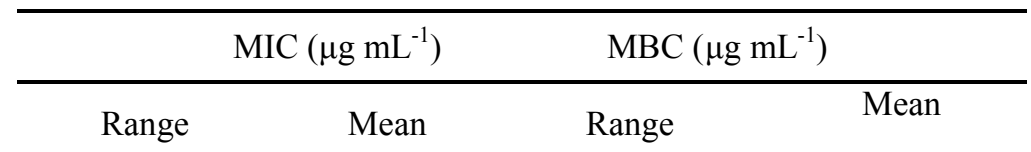

Lippia origanoides

$$
400-800
$$

560

$400-800$

Lippia alba

$800-1600$

1173

$800-1600$

Cymbopogon citratus

$800-1600$

1280

$800-1600$

${ }^{*} \mathrm{MIC}=$ Minimum Inhibitory Concentration; $\mathrm{MBC}=$ Minimum Bactericidal Concentration.

Almeida et al. (2016) in their study on the antiseptic activity of the L. origanoides essential oil, in the presence of bovine milk, highlighted that the antimicrobial activity of the essential oil of this plant was verified, but the data on the antimicrobial activity of essential oils found in the literature are different with respect to the MIC and MBC. These differences could be attributed to the extraction methods, the chemical composition of the essential oil, the microbial strains under testing, and also the test used to analyze the antimicrobial activity. This can explain why the $O$. basilicum essential oil presented no antimicrobial activity against any of the strains used in this study, even though in the literature there are works, such as that by Freire et al. (2014), which attest to its efficiency.

Sartoratto et al. (2004) considered MICs between $50-500 \mu \mathrm{g} \mathrm{mL}^{-1}$ as strong activity; MICs 
between $600-1,500 \mu \mathrm{g} \mathrm{mL^{-1 }}$ as moderate activity, and MICs above $1,500 \mu \mathrm{g} \mathrm{mL}^{-1}$ as low activity. Based on this scale, all essential oils in this study presented antibacterial activity between strong and moderate levels. Despite this, Zamora; Torres; Nuñez (2018) argued that there is no consensus on assessing the antimicrobial activity of a natural product and on an acceptable value for the MIC.

The lowest MIC observed was equal to $400 \mu \mathrm{g} \mathrm{mL} \mathrm{mL}^{-1}$, which was obtained using the $L$. origanoides essential oil. The chemical composition of this essential oil has already been described by several authors, with carvacrol and thymol being identified as the main compounds responsible for the antibacterial activity (ANDRADE et al. 2014; VERAS et al., 2012; ALMEIDA et al., 2016; GUIMARÃES et al. 2014). Besides these authors, Millezi et al. (2014) observed that all the essential oils studied presented antimicrobial activity against $S$. aureus. The chemical composition of these essential oils included $p$-cymene and carvacrol among the major compounds. In view of these results, it may be suggested that the strong activity observed in the L. origanoides essential oil is due to the major presence of carvacrol.

Andrade et al. (2014) affirmed that the $L$. origanoides essential oil does not have toxic effects, providing a high safety margin in addition to having efficient antimicrobial activity against microorganisms such as $S$. aureus. It was also concluded that its use in veterinary medicine should be considered as an economical and sustainable alternative.

The MIC and MBC means for the essential oil of Lippia alba were $1,173 \mu \mathrm{g} \mathrm{mL}^{-1}$ and $1,226 \mu \mathrm{g} \mathrm{mL}{ }^{-1}$, respectively, presenting moderate antimicrobial activity according to the classification by Sartoratto et al. (2004). The EO of Lippia alba showed bacteriostatic and bactericidal activity against different strains of Staphylococcus aureus and other microorganisms isolated from cattle meat (AQUINO et al., 2010). The results obtained in the study by Porfírio et al. (2017) also highlighted the promising antibacterial potential of the essential oil of Lippia alba against $S$. aureus.

In the present study, the essential oil of Cymbopogon citratus presented an MIC of $1,280 \mu \mathrm{g} \mathrm{mL}^{-1}$ and $\mathrm{MBC}$ of $1,333 \mu \mathrm{g} \mathrm{mL}^{-1}$, revealing it to be another option with antimicrobial activity. Zamora; Torres; Nuñez (2018) highlighted that awareness of the importance of searching for substances with antimicrobial activity is more prevalent in the era of antibiotic resistance, and in the last few decades plants have been part of the search for natural sources of these compounds. According to Almeida et al. (2016), the synergism between the compounds of essential oils in antimicrobial activity is mentioned in the literature because of the fact that this class of substances is a complex mixture of different compounds.

\section{CONCLUSION}

The essential oils of $L$. origanoides, L. alba, and $C$. citratus showed positive results for antimicrobial activity against pathogens that cause subclinical mastitis in goats and sheep. Considering the relevance of dairy goat farming in Brazil and the lack of data related to the antimicrobial activity of the studied oils against the main mastitis-causing agents in these animals, it is expected that these results can assist other studies aimed at using these essential oils as a method to control mastitis in small ruminants.

\section{ACKNOWLEDGMENTS}

We would like to thank CNPq for granting the scholarship. We would also like to express gratitude to IF SERTÃO - PE, and the Multi-user Laboratory of Characterization and Analysis of the Research Institute for Drugs and Medicines of the Federal University of Paraíba (LMCA-IPeFarM/UFPB).

\section{REFERENCES}

ALMEIDA A. C. et al. Toxicidade aguda dos extratos hidroalcoólicos das folhas de alecrimpimenta, aroreira e barbatimão e do farelo da casca de pequi administrados por via intraperitoneal. Ciência Rural, 40: 200-204, 2010.

ALMEIDA, A. C. et al. Atividade antisséptica do óleo essencial de Lippia origanoides Cham. (Alecrim-pimenta) na presença de leite bovino. Pesquisa Veterinária Brasileira, 36: 905-911, 2016.

ANDRADE, V. A. et al. Antimicrobial activity and acute and chronic toxicity of the essential oil of Lippia origanoides. Pesquisa Veterinária Brasileira, 35: 1153-1161, 2014.

AQUINO, L. C. L. et al. Atividade antimicrobiana dos óleos essenciais de erva-cidreira e manjericão frente a bactérias de carnes bovinas. Alimentos e Nutrição, 21: 529-535, 2010.

ARAÚJO, L. S. et al. Composição química e susceptibilidade do óleo essencial de óregano (Origanum vulgare L., família Lamiaceae) frente a 
cepas de Escherichia coli, Staphylococcus aureus e Salmonella choleraesuis. Boletim Centro de Pesquisa de Processamento de Alimentos, 33: 7378, 2015.

BURT, S. Essential oils: their antibacterial properties and potential applications in foods - a review. International Journal of Food Microbiology, 94: 223-253, 2004.

CADES, M. et al. Perfil de resistência antimicrobiana de mastite bovina em propriedade leiteira no município de Monte Negro/RO. Revista Brasileira de Ciências da Amazônia, 6: 16-19, 2017.

CLSI - Clinical and Laboratory Standard Institute. Methods for dilution antimicrobial susceptibility 12 tests for bacteria that grow aerobically: Approved standards. 2006. Document CLSI M7A7, CLSI, Wayne, 13 Pennsylvania.

FREIRE, I. C. M. et al. Atividade antibacteriana de óleos essenciais sobre Streptococcus mutans e Staphylococcus aureus. Revista Brasileira de Plantas Medicinais, 16: 372-377, 2014.

FREITAS, M. A. et al. Avaliação in vitro da atividade antimicrobiana do carvacrol através dos métodos de contato direto e gasoso. Bioscience Journal, 29: 781-786, 2013.

GABLI, Z. et al. Prevalence of mastitis in dairy goat farms in Eastern Algeria. Veterinary World, 12: 1563-1572, 2019.

GANDA, E. K. et al. Longitudinal metagenomic profiling of bovine milk to assess the impact of intramammary treatment using a thirdgeneration cephalosporin. Scientific Reports, 6: 1-13, 2016.

GELASAKIS, A. L. et al. Mastitis in sheep-The last 10 years and the future of research. Veterinary Microbiology, 181: 136-146, 2015.

GELASAKIS, A. L. et al. Bacterial subclinical mastitis and its effect on milk yield in low-input dairy goat herds. Journal of Dairy Science, 99: 3698-3708, 2016.

GUIMARÃES L. G. L. et al. Óleo essencial de Lippia sidoides nativas de Minas Gerais: composição, estruturas secretoras e atividade antibacteriana. Revista Ciência Agronômica, 45: 267-275, 2014.

MERZ, A.; STEPHAN, R.; JOHLER, S. Staphylococcus aureus isolates from goat and sheep milk seem to be closely related and differ from isolates detected from bovine milk. Frontiers Microbiology, 7: 1-7, 2016.

MILlEZI, A. F. et al. Caracterização química e atividade antibacteriana de óleos essenciais de plantas condimentares e medicinais contra Staphylococcus aureus e Escherichia coli. Revista Brasileira de Plantas Medicinais, 16: 18-24, 2014.

NASCIMENTO, R. S.; SÁ, R. L.; FORTUNA, J. L. Antimicrobial activity of the essential oil of leaf and fruit of Schinusterebinthifolius (raddi) against Staphylococcus aureus and Escherichia coli. Brazilian Journal of Animal and Environmental Research, 3: 509-521, 2020.

OLECHNOWICZ, J.; JAŚKOWSKI, J. M. Mastitis in small ruminants. Medycyna Veterynaryjna, 70: 67-72, 2014.

OLIVEIRA, S. C. C. et al. Extratos de plantas brasileiras no controle da bactéria Staphylococcus aureus causadora da mastite contagiosa em bovinos leiteiros. Revista Tecnológica, 27: 48-58, 2019.

PORFÍRIO, E. M. et al. In vitro antibacterial and antibiofilm activity of Lippia alba essential oil, citral, and carvone against Staphylococcus aureus. Scientific World Journal, 2017: 1-7, 2017.

POZZO, M. D. et al. Antimicrobial activities of essential oils extracted from spices against Staphylococcus spp isolated from goat mastitis. Ciência Rural, 41: 667-672, 2011.

RAINARD, P. et al. Knowledge gaps and research priorities in Staphylococcus aureus mastitis control. Transboundary and Emerging Diseases, 65: 149165, 2017.

REIS, J. B. et al. Evaluation of antimicrobial activity of essential oils against food Pathogens. Brazilian Journal of Health Review, 3: 342-363, 2020.

SARTORATTO, A. et al. Composition and antimicrobial activity of essential oils from aromatic plants used in Brazil. Brazilian Journal of Microbiology, 35: 275-280, 2004.

VALERIANO, C. et al. Antimicrobial activity of essential oils against sessile and planktonic pathogens of food source. Revista Brasileira de Plantas Medicinais, 14: 57-67, 2012.

VERAS, H. N. H. et al. Topical antiinflammatory activity of essential oil of Lippia sidoides Cham: possible mechanism of action. Phytotherapy Research, 27: 179-185, 2012. 
ZAMORA, C. M. P.; TORRES, C. A.; NUÑEZ, M.

B. Antimicrobial activity and chemical composition of essential oils from Verbenaceae species growing in South America. Molecules, 23: 1-21, 2018.

ZHAO, Y. et al. Shifted T Helper Cell Polarization in a Murine Staphylococcus aureus Mastitis Model.

PloS One, 10: 1-15, 2015. 